\title{
GINSENG EITHER CURATIVE OR PROPHYLACTIC INHIBITS HYPERGLYCEMIA AND OXIDATIVE STRESS IN DIABETIC RATS \\ Ali, S.H. ${ }^{*}$; Eveleen S. Abdalla ${ }^{\star *}$; M.M. Said ${ }^{\star * *}$ and Sabah A. I. Ahmed ${ }^{\star *}$ \\ * Biochemistry Dept. Fac. Agric. Ain Shams Univ. Shoubra El-Kheima. \\ ** Home Economics Fac. Specific Education; Ain Shams Univ. \\ *** Biochemistry Dept., National Organanization for Drug Control and Research, (NODCAR) Cairo, Egypt.
}

\begin{abstract}
In the present work 40 female albino rats were divided into two main groups Prophylactic and Curative. Prophylactic was treated with ginseng for four weeks before and after the induction of diabetes, while curative was treated with ginseng only after the induction of diabetes, besides, non treated control, Ginseng control and Diabetic control (each group 8 rats). Two main experiments were carried out. The first experiment represented the effect of ginseng as prophylactic agent against hyperglycemia induced by streptozotocin (STZ). The second depended on the curative effect of these treatments on hyperglycemic rats. Antioxidant parameters that protect the cell against reactive oxygen species (ROS) were carried out. Activities of antioxidant enzymes catalase (CAT) were measured. In addition, levels of antioxidant biomolecules involving glutathione (GSH), L-Ascorbic acid (vitamin C). Also, lipid profile and lipid peroxidation malondialdehyde (MDA) were measured. Data revealed that Ginseng roots supplementation improved blood sugar levels in diabetic rats and protected rats from diabetic factors like streptozotocin in prophylactic female albino rats.
\end{abstract}

Keywords: Ginseng, Antioxidant biomolecules, Diabetes, Prophylactic, Curative Blood \& Plasma parameters.

*Safwatali@hotmail.com

\section{INTRODUCTION}

Diabetes mellitus (DM) is a metabolic disorder characterized by chronic hyperglycemia associated with absolute or relative deficiencies in insulin secretion or function. Diabetes mellitus is usually irreversible and its late complications resulted in reduced life expectancy (Paul 1997).

Reactive oxygen species (ROS) are various forms of activated oxygen, which include free radicals such as superoxide anion $\left(\mathrm{O}_{2}{ }^{-}\right)$, hydroxyl radical (HO) and peroxyl radical (ROO-), as well as reactive non-radical compounds such as singlet oxygen, peroxynitrite and hydrogen peroxide (Stahl and Sies, 1997). ROS arise as by products of normal metabolism and as a result of exposure to sunlight, ozone, radiation and other environmental pollutants.

A cellular depletion of the antioxidants and higher levels of free radicals were found in diabetes (Obrosova et al., 2003). Diabetes mellitus and hyperglycemia are a widely known cause of enhanced plasma free radicals concentrations, which is believed to associated with increased oxidative stress (Wolff and Dean, 1987; Baynes, 1992 and Pieper et al., 1995). Clinical and experimental evidence has suggested the involvement of free radicals- 


\section{Ali, S.H. et al.}

mediated oxidative damage to be a contributor factor in development and complications of diabetes (Damasceno et al., 2002 and Dincer et al., 2002). Cho et al. (2004), reported that abnormal glucose metabolism leads to oxidative stress and diabetic rats had higher serum levels of superoxide and nitrite/nitrate. This over-production of radicals associated with diabetes. Glucose autoxidation is believed to represent the main source of free radicals under conditions of hyperglycemia (Wolff and Dean 1987).

Oxidative stress plays a dominant role in the pathogenesis of diabetes mellitus (Huang, et al., 2006). Oxidative stress has been associated with the pathogenesis of chronic diabetic complications, (Cai and Kang, 2003). Recently, the ability of antioxidants to inhibit these injuries has raised the possibility of newer therapeutic treatment for preventing oxidant-induced cell death and in decreasing radical oxygen production (Jang and Surh, 2003). Generally, if diabetes mellitus left untreated, it may be initiate degenerative process and other central nerves system (CNS) complications due to accumulation of oxidative free radicals. (Ramanathan,1999). On the other hand, glycemic control was found to reduce the oxidative damage in diabetes (Renu, 2003).

Antioxidants have important therapeutic potential in conditions where oxidative stress is involved (Dincer et al., 2002). In addition, KedzioraKomatowska et al. (2000) confirmed the presence of oxidative stress in streptozotocin induced experimental diabetes and pointed to the beneficial antioxidants effect. Ginseng roots have been found recently to help and protect against cancer (Helms, 2004), cardiovascular disease (Zhou et al., 2004), and stress (Kaneko and Nakanishi, 2004). Also, antioxidants improve memory (Lian et al., 2005 \& Nishijo et al., 2004), and reduced colds (Predy, 2005). These health-promoting effects are thought to be due to the high levels of antioxidants in ginseng (ginsenosides) (Attele, 1999). The herb "ginseng" is actually several different types of plants, mainly Korean or Asian ginseng (Panax ginseng), Siberian ginseng (Eleutherococcus senticosus), and American ginseng (Panax quinquefolius). Panax ginseng has been an important herbal remedy in traditional Chinese medicine for thousands years, where it has been used primarily as a treatment for weakness and fatigue (Mahady et al., 2000). Recently, Wang et al. (2006) found that ginseng extract inhibits lipolysis in rat adipocytes in vitro by activating phosphodiesterase 4 (PDE4) enzyme. In addition, Jung (2005) confirmed the effectiveness of wild Panax ginseng leaf extract (WGLE) supplementation in detoxifying free radicals that are produced excessively in diabetic-induced complications.

The present study was established on two ways, curative and protective levels to investigate the effect of ginseng on hyperglycemia by streptozotocin-induced diabetes (STZ) and assay the activities of oxidant and antioxidant enzymes in the diabetic rats. Also, to evaluate through biochemical assays if ginseng could prevent the depletion of endogenous anti-oxidants, lipid peroxidation, inhibits the formation of reactive oxygen and scavenge oxygen free radicals, which mean that ginseng may provide greater benefit for hyperglycemia and diabetes mellitus that synergize with its antioxidant actions. 


\section{MATERIALS AND METHODS}

\section{Materials:}

Animals

Forty female albino Sprague-Dawley rats weight $130 \mathrm{~g} \pm 10$ were purchased from the National Organization for Drug Control and Research (NODCAR), Giza, Egypt. The animals were housed in stainless steel experimental animal's cages in air condition room at a constant temperature of $(21 \pm 2){ }^{\circ} \mathrm{C}$, with a $12 \mathrm{~h}$ light/dark cycle. Rats were kept for one week to adapt the laboratory conditions before starting the experiment, and maintain on the free access of water and a balanced diet.

\section{Diets:}

Balanced diet was prepared daily according to (Ali, 1991). The composition of rat's diet is shown in Table (1).

Table 1. Composition of the Balanced Diet in Gram.

\begin{tabular}{|c|c|c|c|c|c|c|}
\hline Source & $\begin{array}{c}\text { Final } \\
\text { Weight }\end{array}$ & $\begin{array}{c}\text { Total } \\
\text { Calories }\end{array}$ & $\begin{array}{l}\text { Crude } \\
\text { Protein }\end{array}$ & $\begin{array}{l}\text { Crude } \\
\text { Fiber }\end{array}$ & $\begin{array}{c}\text { Crude } \\
\text { Fat }\end{array}$ & $\begin{array}{c}\text { Carbo- } \\
\text { hydrates }\end{array}$ \\
\hline Balady Bread * & 100 & 260 & 8.2 & 0.5 & 3.3 & 58.3 \\
\hline $\begin{array}{l}\text { Milk powder ** } \\
\text { (Whole Fat) }\end{array}$ & 30 & 125 & 6.37 & ---- & 6.87 & 9.37 \\
\hline Carrot *** & 15 & 6.3 & 0.15 & 0.12 & 0.04 & 1.2 \\
\hline Cucumber *** & 15 & 2.55 & 0.10 & 0.06 & 0.01 & 0.45 \\
\hline
\end{tabular}

* Balady Bread was purchased from bakeries of North Giza.

** Whole fat milk powder was purchased from (NODCAR).

*** Carrot and Cucumber were purchased from local market.

\section{Preparation of ginseng root for rat's diet:}

Daily $500 \mathrm{mg}$ of ginseng root $/ \mathrm{Kg}$ rat's body weight according to Nariman, (1997) and Vuksan et al. (2000) were taken and pulverized using the grinder. Then they were mixed well manually by a spoon in $20 \mathrm{~g}$ of the balanced diet and introduced to the rats to make sure that rats ate the complete dose from ginseng root then complete the balanced diet. Ginseng Root (Korean ginseng root) (translucent, yellowish-brown), was purchased from Agricultural Seeds, Spices and Medicinal Plants Co. (Abd-El-Rahman M. Harras), Bab El-khalk, Cairo, Egypt.

\section{Induction of diabetes:}

Diabetes was induced by a multi dose of Streptozotocin (STZ) (27.5 $\mathrm{mg} / \mathrm{kg}$ b.w) as previously described (Said et al., 2000). The survived prediabetic rats were subjected to booster injection with five successive doses $(11.25 \mathrm{mg} / \mathrm{kg}$ b.w.) each week intervals. STZ used was purchased from Sigma Chemical Co., St Louis, Mo, USA. About 72 hours after STZ injection, blood samples were taken from the retro-orbital plexus veins, and glucose levels were measured to make sure of the induction of diabetes and those rats became hyperglycemic. 


\section{Ali, S.H. et al.}

\section{Experimental Design and Groups:}

Age-matched 40 female albino rats were randomly divided into the following five groups 1) Control group (untreated rats were kept on basal diet only for 8 weeks); 2) Ginseng group (rats were treated with certain dose of ginseng $500 \mathrm{mg} / \mathrm{Kg} \mathrm{b.w.);} \mathrm{3)} \mathrm{Diabetic} \mathrm{group} \mathrm{(rats} \mathrm{were} \mathrm{made} \mathrm{diabetic} \mathrm{after} 4$ weeks of experiment and kept only on basal diet); 4) Prophylactic group (rats were treated with certain dose of ginseng $500 \mathrm{mg} / \mathrm{Kg} \mathrm{b.w}$. for 4 weeks after that made diabetic and then, continued supplemented with the same dose of ginseng); 5) Curative group (rats were kept on basal diet for 4 weeks then made diabetic, after that treated with ginseng $500 \mathrm{mg} / \mathrm{Kg} \mathrm{b.w.} \mathrm{for} 4$ weeks.

Table 2. Groups of Treated Rats and Level of Nutrient Supplements.

\begin{tabular}{|c|c|c|c|}
\hline No. & Treatments & Supplementation level & $\begin{array}{l}\text { Experimental } \\
\text { Time }\end{array}$ \\
\hline 1 & (N) Normal Control & Balanced Diet (2) month & 2 Months \\
\hline 2 & (G) Positive Ginseng & Balanced Diet + Ginseng roots $500 \mathrm{mg} / \mathrm{kg}$ b.w (2) month & 2 Months \\
\hline 3 & (D) Positive Diabetic & Balanced Diet (1) month, STZ and Balanced Diet (1) month & 2 Months \\
\hline 4 & (GDG) Prophylactic & $\begin{array}{l}\text { Balanced Diet }+ \text { Ginseng roots } 500 \mathrm{mg} / \mathrm{kg} \text { b.w (1) } \\
\text { month, STZ and Balanced Diet }+ \text { Ginseng roots } \\
500 \mathrm{mg}(1) \text { month }\end{array}$ & 2 Months \\
\hline 5 & (NDG) Curative & $\begin{array}{l}\text { Balanced Diet (1) month, STZ and Balanced Diet }+ \\
\text { Ginseng root } 500 \mathrm{mg} / \mathrm{Kg} \mathrm{b.w} \mathrm{(1)} \mathrm{month}\end{array}$ & 2 Months \\
\hline
\end{tabular}

\section{Methods:}

Collection of blood samples:

Blood samples were collected from retro-orbital plexus veins from the individual rat according to Schermer, (1967) using fine capillary heparinized tubes. Blood was centrifuged at $3500 \mathrm{rpm}$ for $15 \mathrm{~min}$, and then plasma samples were carefully separated and stored frozen for different biochemical analysis.

\section{Body and relative organs weight:}

During the experiments, body weight was recorded every two weeks up to the end of the experimental period ( 8 weeks). At the end of the experimental period ( 8 weeks), the rats were anesthetized with light ether and the heart, liver; kidney and spleen of each rat were removed and weighted compared relatively to the body weight ( $\mathrm{g}$ of organ $/ 100 \mathrm{~g}$ live body weight).

\section{Biochemical analysis:}

\section{Determination of Blood Parameters:}

Blood hemoglobin was determined according to Van Kampen and Zijlstra (1961). Total protein was determined according to Bradford method (1976), Plasma glucose was determined according to Trinder method (1969), plasma lipids profile were determined as follow: 1) Plasma total lipids were determined according to the method of knight et al. (1972). 2) Plasma total cholesterol was measured as mentioned by Flegg (1973), 3) Plasma high density lipoprotein-cholesterol (HDL-C) was determined using the method of Fruchart (1982); LDL-C \& VLDL-C were determined as described by Friedewald et al. (1972). 4) Plasma triglycerides were done enzymatically according to the method of Fossati and Prencipe (1982). 


\section{Determination of Antioxidants markers:}

a) Malondialdehyde (MDA) was done according to method of Uchiyama and Mihara (1978). MDA value was estimated according to Strove and Makarova (1989). b) Blood Glutathione (GSH) was determined according to the method of Beutler, et al. (1963). c) Catalase (CAT) was done according to the method of Sinha (1972). d) Vitamin C was measured as the method of Jagota and Dani (1982).

\section{Statistical analysis}

Data were presented as means \pm standard error (SE). Student's t-test was used for evaluating the statistical significance of differences in means according to the method described by (Chase, 1967).

\section{RESULTS AND DISCUSSION}

\section{Body and Organs Weight}

Table (3) revealed to the prophylactic and the curative effect of ginseng on body weight and body weight gain compared to the normal and diabetic groups. Data obtained showed insignificant difference between all groups on initial body weight. However, final body weight in diabetic group significantly decreased in comparison to control body weight. Similar finding were obtained by Obrosova et al. (2003) who reported that final body weight in rats treated with STZ-induced diabetes was lower than in non-diabetic rats, while the initial body weight was the same.

Decreasing on body weight and body weight gain also was observed in diabetic group treated with ginseng in prophylactic and curative experiments. These results are in agreement with those of Dey et al. (2003) who found that body weight in obese-diabetic mice was not changed significantly after the treatment with ginseng root. On the other hand, body weight and body weight gain of normal rats treated with ginseng were not affected significantly compared to normal control group. Similar findings were obtained by Yu et al. (2005) who found that body weight gain in normal rats was not changed significantly after treated with panax ginseng. While, different results were obtained by Osfor et al. (2002) who indicated that treatment with ginseng increased body weight in normal albino rats.

Table 3. Effect of Ginseng Supplemented Diets on Body Weight in Normal \& Diabetic Female Albino Rats.

\begin{tabular}{clcccc}
\hline $\begin{array}{c}\text { No.of } \\
\text { Group }\end{array}$ & Animal groups & $\begin{array}{c}\text { Initial } \\
\mathbf{( g )}\end{array}$ & $\begin{array}{c}\text { Final } \\
\mathbf{( g )}\end{array}$ & $\begin{array}{c}\text { Gain } \\
\mathbf{( g )}\end{array}$ & $\begin{array}{c}\text { Changing } \\
\mathbf{( \% )}\end{array}$ \\
\hline $\mathbf{1}$ & Normal Control & $139.6 \pm 4.04$ & $184.4 \pm 3.68$ & 44.8 & 32.1 \\
$\mathbf{2}$ & Ginseng & $136.7 \pm 5.43$ & $178.8 \pm 6.06$ & 42.1 & 30.8 \\
$\mathbf{3}$ & Diabetic & $137.3 \pm 3.80$ & $155.2 \pm 6.05^{*}$ & $17.9^{*}$ & 15.4 \\
$\mathbf{4}$ & Ginseng-Diabetic & $136.0 \pm 2.82$ & $157.6 \pm 4.60^{*}$ & 21.6 & 15.9 \\
$\mathbf{5}$ & Diabetic-Ginseng & $130.4 \pm 4.13$ & $153.0 \pm 5.87^{*}$ & $22.6^{*}$ & 17.3 \\
\hline
\end{tabular}

Each value represents the mean of 8 rats \pm S.E

* Significant difference from the corresponding control at $\mathbf{P}<0.05$ 


\section{Ali, S.H. et al.}

\section{Relative organs weight:}

Table (4) indicated to the prophylactic and curative effect of ginseng on relative organs weight in normal and diabetic rats. The data showed that the relative percentage of heart weight in all groups values statistically were insignificant. In addition, data revealed non-significant effect on relative liver weight. Also, relative kidney weight was insignificantly affected in normal and diabetic rats. Meanwhile, relative spleen weight decreased but not significantly in diabetic compared to normal group. Moreover, results of curative study showed insignificant decrease in relative spleen weight in diabetic group which treated with ginseng in comparison to diabetic group in prophylactic study that treated with ginseng.

These data are coincided with that of Yu et al. (2005) who reported that treatment with panax ginseng had no effect on relative liver weight in adult rats. While, Aphala et al. (1998) found that liver weight was significantly increased in rats treated with panax ginseng. Also, Ali (1991) found that liver weight increased significantly in diabetic rats. Meanwhile, Gallaher et al. (1992) noticed that, relative kidney weights were significantly greater in diabetic groups than in the normal groups. Also Nandini et al. (2003) found that, relative weight of kidney increased during diabetes in rats. However, the present data were in agreement with those obtained by Ali, (1991) who reported that diabetes caused highly significant decrease on weight of spleen, while diabetes was not affected on heart weight.

Table 4. Effect of Ginseng Supplemented Diets on Relative Organs Weight in Normal and Diabetic Female Albino Rats.

\begin{tabular}{clcccc}
\hline $\begin{array}{c}\text { Group } \\
\text { No. }\end{array}$ & Animal groups & Heart & Liver & Kidney & Spleen \\
\hline $\mathbf{1}$ & Normal Control & $0.33 \pm 0.01$ & $3.13 \pm 0.16$ & $0.53 \pm 0.02$ & $0.37 \pm 0.02$ \\
$\mathbf{2}$ & Ginseng & $0.33 \pm 0.02$ & $3.08 \pm 0.23$ & $0.58 \pm 0.02$ & $0.40 \pm 0.02$ \\
$\mathbf{3}$ & Diabetic & $0.34 \pm 0.01$ & $3.02 \pm 0.13$ & $0.54 \pm 0.01$ & $0.33 \pm 0.03$ \\
$\mathbf{4}$ & Ginseng-Diabetic & $0.33 \pm 0.01$ & $3.11 \pm 0.27$ & $0.55 \pm 0.03$ & $0.41 \pm 0.03$ \\
$\mathbf{5}$ & Diabetic-Ginseng & $0.35 \pm 0.01$ & $3.24 \pm 0.14$ & $0.56 \pm 0.04$ & $0.33 \pm 0.01$ \\
\hline
\end{tabular}

Each value represent the mean of 8 rats \pm S.E

* Significant difference from the corresponding control at $\mathrm{P}<0.05$

\section{Blood hemoglobin $(\mathrm{Hb})$}

Data in Table (5) presented the curative results of blood $\mathrm{Hb}$. The levels of $\mathrm{Hb}$ statistically were not affected despite the slight increase which observed after 8 weeks in curative group corresponding to diabetic control group and normal control group. The elevation of $\mathrm{Hb}$ associated with ginseng treatment was not high, but the slight elevation proved that ginseng may be having some effects on $\mathrm{Hb}$ level on diabetic rats. This effect may be due to the antioxidant properties of ginseng against free radicals, which affected on $\mathrm{Hb}$ concentration. 


\section{Blood Glucose:}

Data in Table (5) represented that, plasma glucose in normal group was not affected during the 8 weeks of experiment. The induction of diabetes with STZ led to elevation of plasma glucose in diabetic control group. While, the values significantly was lower after 4 and 8 weeks in prophylactic group treated with ginseng However, the values were not changed significantly in normal groups, which treated with ginseng.

Data of prophylactic study revealed that STZ which induces hyperglycemic effect in treated rats led to increase plasma glucose level after 8 weeks by $90.27 \%$ in diabetic group compared to control (non diabetic). However, the hyperglycemia was decreased significantly after ginseng treatment by $58.48 \%$ and $48.32 \%$ respectively compared to diabetic control group after 4 and 8 weeks respectively. Also, data of curative study showed that treatment with ginseng decreased blood glucose levels by $3.67 \%$ and $24.1 \%$ after four and eight weeks respectively compared to diabetic control group.

It is pointed out that the lowering effect of ginseng on blood glucose levels was a remarkable effect in prophylactic experiment, which markedly showed the ginseng role in curative experiment. The lowering effect of blood glucose in ginseng groups may be attributed to ginsenosides (the effective components in ginseng) which decreased blood glucose as mentioned by Dey et al. (2003).

\section{Total protein:}

Plasma levels of total protein (Table, 5) were not statistically changed after induction of diabetes with STZ, in diabetic groups compared to normal control group in both prophylactic and curative studies. However, different results were obtained by Nariman (1997) and Akula et al. (2003) who found that induction of diabetes with STZ decreased total protein level. Also, Wasif (1997) and Mansour et al. (2002) showed that, the level of total protein was significantly decreased in alloxan diabetic rats.

However, treatment with ginseng resulted in slight increase in total protein levels of normal rats after 8 weeks. However, treatment with ginseng led to significant increase of total protein in diabetic rats, only in prophylactic study where the values were $(8.71 \pm 0.15 \mathrm{~g} / \mathrm{dl})$ compared to $(6.23 \pm 0.09 \mathrm{~g} / \mathrm{dl})$ in diabetic control group after 8 weeks. Similar findings were obtained by Nariman (1997) who reported that, when ginseng was supplemented to normal rats, slightly increase in serum total protein was found in comparison to control rats, while when ginseng was administrated to STZ-diabetic rats, total protein levels were greatly elevated compared with the untreated control rats. Also, it is noteworthy that insulin stimulates the incorporation of amino acids into protein (Ganong, 1983). Therefore, the stimulatory effects of panax ginseng on protein synthesis may be attributed to the presence of insulin like substances in its components as reported by (Takaku et al., 1988; Murase at al., 1994). Also, in support, other studies have concluded that ginseng components stimulate insulin production by the pancreas (Kimura et al., 1981). 
Ali, S.H. et al.

Table 5. Prophylactic and Curative Effects of Ginseng on Blood Hemoglobin, Plasma Glucose and Plasma Total Protein in Normal and Diabetic Female Albino Rats.

\begin{tabular}{|c|c|c|c|c|c|c|}
\hline Parameter & Weeks & Control & Ginseng & Diabetic & Prophylactic & Curative \\
\hline $\begin{array}{l}\text { Haemoglobin } \\
\text { g/dl }\end{array}$ & $\begin{array}{c}\text { Zero } \\
4 \\
8\end{array}$ & $\begin{array}{l}12.90 \\
\pm 0.45 \\
13.00 \\
\pm 0.34 \\
13.50 \\
\pm 0.46 \\
\end{array}$ & $\begin{array}{l}13.20 \\
\pm 0.65 \\
13.20 \\
\pm 0.30 \\
12.00 \\
\pm 0.34 \\
\end{array}$ & $\begin{array}{l}13.10 \\
\pm 0.20 \\
12.70 \\
\pm 0.28 \\
14.80 \\
\pm 0.70 \\
\end{array}$ & $\begin{array}{l}12.50 \\
\pm 0.24 \\
13.20 \\
\pm 0.22 \\
12.30 \\
\pm 0.19 \\
\end{array}$ & $\begin{array}{l}12.90 \\
\pm 0.27 \\
13.20 \\
\pm 0.34 \\
15.50 \\
\pm 0.74 \\
\end{array}$ \\
\hline $\begin{array}{l}\text { Mean } \\
\pm S E \\
\end{array}$ & & $\begin{array}{r}13.30 \\
\pm 0.25 \\
\end{array}$ & $\begin{array}{r}12.60 \\
\pm 0.60 \\
\end{array}$ & $\begin{array}{r}13.80 \\
\pm 1.05 \\
\end{array}$ & $\begin{array}{r}12.80 \\
\pm 0.45 \\
\end{array}$ & $\begin{array}{r}14.30 \\
\pm 11.5 \\
\end{array}$ \\
\hline $\begin{array}{l}\text { Glucose } \\
\mathrm{mg} / \mathrm{dl}\end{array}$ & $\begin{array}{c}\text { Zero } \\
4 \\
8\end{array}$ & $\begin{array}{l}59.90 \\
\pm 4.79 \\
67.70 \\
\pm 0.83 \\
72.00 \\
\pm 4.59 \\
\end{array}$ & $\begin{array}{c}58.00 \\
\pm 2.88 \\
60.50 \\
\pm 3.01 \\
60.2 \\
\pm 5.01 \\
\end{array}$ & $\begin{array}{c}55.70 \\
\pm 5.00 \\
139.0 \\
\pm 2.39^{\star *} \\
137.0 \\
\pm 7.82^{\star *} \\
\end{array}$ & $\begin{array}{c}58.40 \\
\pm 3.89 \\
57.70 \\
\pm 2.63 \\
70.80 \\
\pm 2.72^{* *} \\
\end{array}$ & $\begin{array}{c}56.30 \\
\pm 3.65 \\
133.9 \\
\pm 5.60^{\star *} \\
104.0 \\
\pm 10.3 \\
\end{array}$ \\
\hline $\begin{array}{l}\text { Mean } \\
\pm S E \\
\end{array}$ & & $\begin{array}{r}69.85 \\
\pm 2.15 \\
\end{array}$ & $\begin{array}{r}60.35 \\
\pm 0.15 \\
\end{array}$ & $\begin{array}{c}138.0 \\
\pm 1.0 \\
\end{array}$ & $\begin{array}{r}64.25 \\
\pm 6.55 \\
\end{array}$ & $\begin{array}{r}118.95 \\
\pm 14.95 \\
\end{array}$ \\
\hline $\begin{array}{l}\text { Total Protein } \\
\text { g/dl }\end{array}$ & $\begin{array}{c}\text { Zero } \\
4 \\
8\end{array}$ & $\begin{array}{c}6.23 \\
\pm 0.23 \\
6.41 \\
\pm 0.19 \\
6.36 \\
\pm 0.15 \\
\end{array}$ & $\begin{array}{l}6.940 \\
\pm 0.23 \\
6.630 \\
\pm 0.15 \\
7.260 \\
\pm 0.18 \\
\end{array}$ & $\begin{array}{l}6.500 \\
\pm 0.15 \\
6.750 \\
\pm 0.11 \\
6.230 \\
\pm 0.09 \\
\end{array}$ & $\begin{array}{c}7.80 \\
\pm 0.36 \\
6.90 \\
\pm 0.24 \\
8.71 \\
\pm 0.15^{\star \star} \\
\end{array}$ & $\begin{array}{c}6.270 \\
\pm 0.08 \\
6.65 \\
\pm 0.16 \\
6.00 \\
\pm 0.14 \\
\end{array}$ \\
\hline $\begin{array}{l}\text { Mean } \\
\pm S E\end{array}$ & & $\begin{array}{c}6.38 \\
\pm 0.02\end{array}$ & $\begin{array}{c}6.94 \\
\pm 0.31\end{array}$ & $\begin{array}{c}6.49 \\
\pm 0.26\end{array}$ & $\begin{array}{c}7.81 \\
\pm 0.91\end{array}$ & $\begin{array}{c}6.33 \\
\pm 0.32\end{array}$ \\
\hline
\end{tabular}

Each value represents the mean of 8 rats \pm S.E; Mean \pm SE $=$ represents the mean after induction of diabetes. ${ }^{*} \&{ }^{\star \star}$ mean Significant $\&$ Highly significant difference at $P<0.05 \& P<0.01$ respectively.

\section{Lipid Profile:}

\section{Total Lipids (TL)}

The prophylactic effect of ginseng on plasma total lipids was presented in Table (6). Data showed that plasma total lipids values in all groups at zero time were statistically insignificant. However, after 4 weeks the values of plasma total lipids were decreased in group treated with ginseng compared to control group. On the other hand, the induction of diabetes by STZ led to increase plasma total lipids in diabetic control group. While, in treated group with ginseng showed insignificant decrease of total lipids in prophylactic group.

Table (6) presented the curative effect of ginseng on plasma total lipids. Data obtained revealed that, after, induction of diabetes the plasma total lipids were increased significantly in diabetic groups, these change was highly significant compared to normal control and at zero time. However, after 8 weeks, plasma total lipids were significantly decreased to $256.2 \pm 8.45$ $\mathrm{mg} / \mathrm{dl}$ in curative diabetic group treated with ginseng.

Results of prophylactic study revealed that, ginseng had insignificant effect on plasma total lipids during the experimental period. The curative effect of ginseng on plasma total lipids showed that this supplementation significantly decreased total lipids by $37.3 \%$ compared to diabetic group. 


\section{Triglycerides (TG)}

Prophylactic data in Table (6) revealed that plasma TG were statistically insignificant in group at zero time. Also, after four weeks, plasma TG was not changed in control groups, while significant decrease was observed in all treated groups with ginseng. However, the induction of diabetes led to a significant increase of plasma TG in diabetic control group compared to normal control group. While, the prophylactic values in diabetic groups treated with ginseng were significantly decreased. Also, TG levels in normal groups which treated with ginseng significantly decreased.

The curative effect of ginseng on plasma TG was shown in Table (6). At zero time, TG was not statistically affected. However, after the induction of diabetes, TG significantly increased in diabetic groups compared to normal control group. At the end of experimental period, after 8 weeks, administration of ginseng significantly decreased plasma TG from (140.5 \pm 17.5 to $55.4 \pm$ $5.50 \mathrm{mg} / \mathrm{dl})$.

The present data showed that plasma TG levels decreased due to ginseng treatment in normal or diabetic rats. In prophylactic study the lowering effect of ginseng on TG levels were $62.48 \%$ and $45.97 \%$ compared to diabetic control group after four and eight weeks respectively. On the other hand, in curative study treatment with ginseng led to decrease of plasma TG levels to $60.6 \%$ after eight weeks in diabetic group treated with ginseng compared to non treated diabetic group.

It is shown that the lowering effect of ginseng on plasma TG levels was markedly noticed more in curative than prophylactic experiment where the lowering after 8 weeks was $60.6 \%$ compared to $45.97 \%$ in prophylactic and curative ginseng respectively. This lowering of plasma TG due to ginseng treatment may be attributed to ginsenosides which considers the main effective substance in this supplementation. These results are coincided with Smith (1997) who mentioned that plasma TG concentration was elevated by STZ induced diabetes in the non-diabetic rats. Meanwhile, Morgan and Cupp, (2000) reported that ginseng reduced TG in rats.

\section{Total Cholesterol (TC)}

The prophylactic data of ginseng on plasma T. cholesterol was tabulated in Table (6). Data obtained revealed that plasma T. cholesterol at zero time and after 4 weeks were not significantly affected. Meanwhile, plasma TC slightly decreased due to ginseng treatment in prophylactic group comparison to diabetic group. In addition, little lowering was shown in TC in ginseng group.

On the other hand, curative results of plasma total cholesterol are shown in Table (6). Data obtained revealed that plasma T. cholesterol were not affected significantly after 4 weeks in curative group. This indicates that, after the induction of diabetes, the mean values of plasma T. cholesterol were not changed significantly due to ginseng treatment. On the other hand, after 8 weeks plasma T. cholesterol decreased significantly in curative group and reached $67.4 \pm 0.56 \mathrm{mg} / \mathrm{dl}$. 
Ali, S.H. et al.

Generally, plasma T. cholesterol levels, at the beginning of two experiments (prophylactic and curative), were not significantly changed between all groups. Then, after the induction of diabetes with STZ, plasma T. cholesterol levels were slightly changed in diabetic rats compared to normal group. This may be attributed to growth retardation because the lowering of serum cholesterol levels has previously been documented with the restriction of calorie intake in humans (McDermott et al. 1995). However, this reduction in plasma T. cholesterol level was insignificant in prophylactic study.

On the other hand, data of curative study showed that treatment with ginseng significantly reduced plasma $\mathrm{T}$. cholesterol levels in diabetic rats. This result coincided with Attele et al. (2002) who reported that panax ginseng reduced plasma $\mathrm{T}$. cholesterol in obese diabetic mice.

Table 6. Prophylactic and Curative Effect of Ginseng on Plasma Lipid Profile in Normal and Diabetic Female Albino Rats.

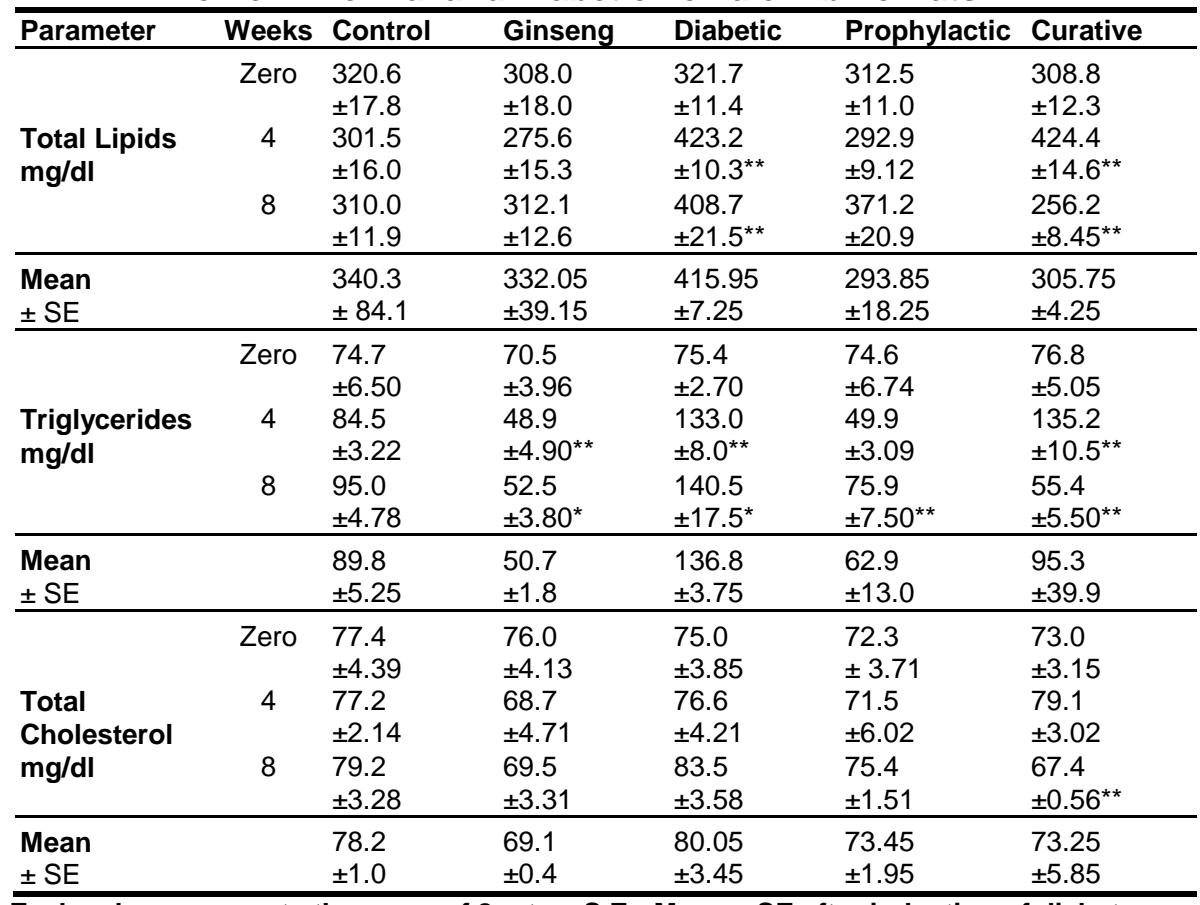

Each value represents the mean of 8 rats \pm S.E ; Mean \pm SE after induction of diabetes.

* \& ** mean Significant \& Highly significant difference at $\mathbf{P}<0.05$ \& $\mathbf{P}<0.01$ respectively.

LIPOPROTEINS (HDL, LDL and VLDL)

High Density Lipoprotein-Cholesterol (HDL-C):

Table (7) showed the prophylactic effect of ginseng on plasma HDLC. Data obtained showed that at zero time, there were not significantly variations observed between all groups. Meanwhile, plasma HDL-C was significantly increased in ginseng group after 4 weeks compared to control group. However, after the induction of diabetes with STZ, plasma HDL-C revealed some decrease in diabetic control group compared to normal control group. In contrary, prophylactic group revealed significant increase in plasma HDL-C compared to diabetic control group. 
Table 7. Prophylactic and Curative Effect of Ginseng on Plasma Lipoproteins in Normal and Diabetic Female Albino Rats.

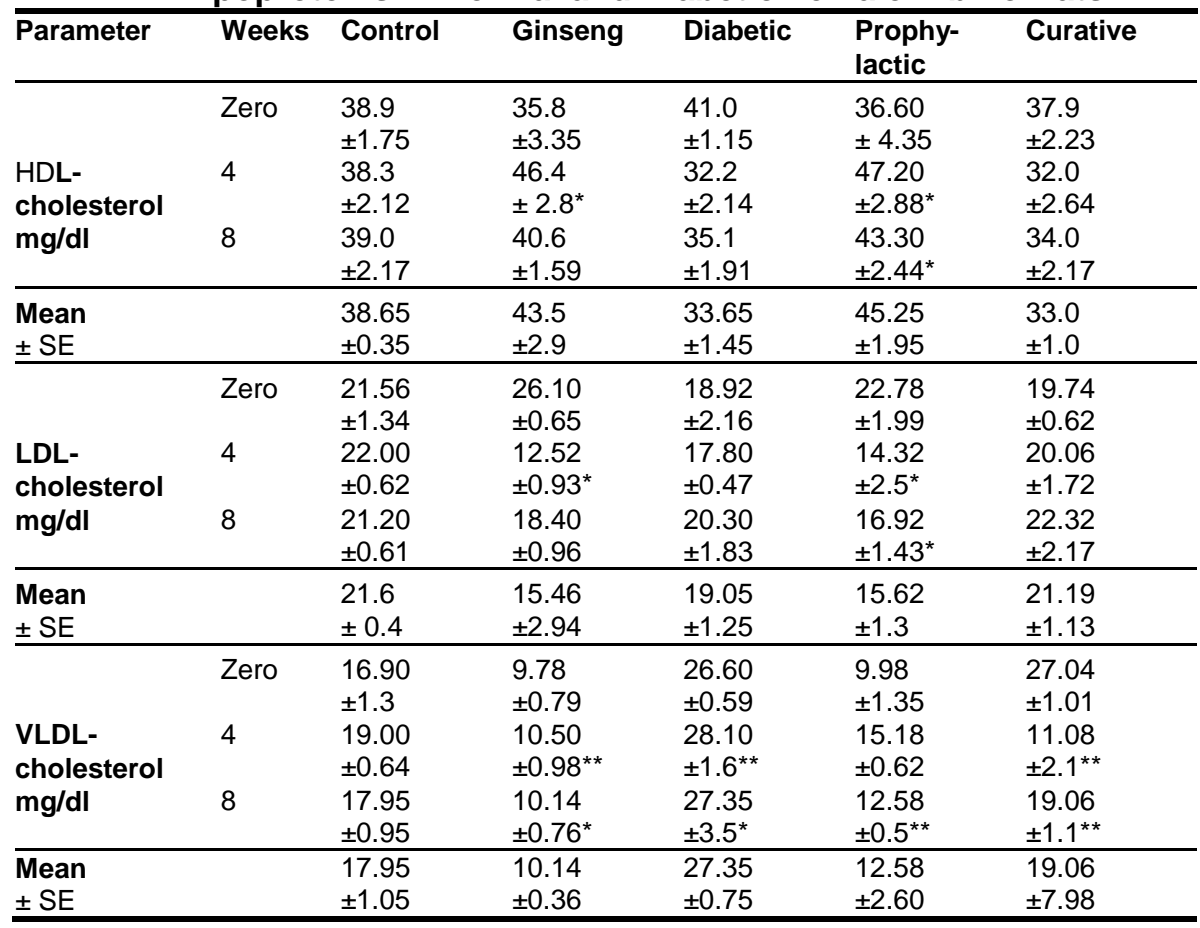

Each value represents the mean of 8 rats \pm S.E; Mean \pm SE after induction of diabetes.

* \& ** mean Significant \& Highly significant difference at $P<0.05 \& P<0.01$ respectively.

On the other hand, the curative effect of ginseng on plasma HDL-C in diabetic rats was shown in Table (7). Data obtained of plasma HDL-C at 4 weeks after the induction of diabetes revealed non significant variation between diabetic and curative groups. On the other hand, at the end of the experimental period after eight weeks, plasma HDL-C was lowered to $34.0 \pm$ $2.17 \mathrm{mg} / \mathrm{dl}$ in curative group. This result means that ginseng was not effective in remediate HDL lowering in curative study.

Also, data in Table (7) showed that ginseng treatment resulted in significant reduction in LDL-C in ginseng group compared with all treated groups. This reduction may be attributed to the significant increase in HDL-C in this group. However, prophylactic treatment revealed significant reduction in LDL-C compared to both control and diabetic groups. In addition, VLDL-C was also decreased in ginseng group, while diabetic group showed significant increase in VLDL-C. Meanwhile both prophylactic and curative groups revealed significant lowering in LDL-C due to ginseng treatments.

Generally, data obtained showed that plasma HDL-C in prophylactic study was increased due to ginseng treatment after four weeks in normal rats. These findings are consistent with Yamamoto et al. (1983) who found that treatment with ginseng led to increase HDL-C in a pilot study. Also, the data 


\section{Ali, S.H. et al.}

was in agreement with Kim and Park (2003) who found that administration of panax ginseng led to increase HDL-C in humans. On the other hand, after 8 weeks ginseng effect was markedly observed only in prophylactic diabetic group, where HDL-C levels increased by $23.36 \%$ compared to diabetic control group. Moreover, curative study showed that ginseng supplementation had no significant effect on plasma HDL-C.

\section{Antioxidants Markers:}

\section{Lipid Peroxidation Malondialdehyde (MDA):}

Table (8) reveals the prophylactic effect of ginseng on plasma MDA. The differences between plasma MDA values were not significant at zero time. However, induction of diabetes with STZ led to increase plasma MDA significantly in diabetic control group to $11.6 \pm 1.92 \mathrm{nmol} / \mathrm{ml}$ compared to 7.53 \pm 1.82 in normal control group. Meanwhile, ginseng treatment led to significant decrease on plasma MDA in prophylactic group comparison to diabetic control group.

Curative data in Table (8) showed that plasma MDA in rat group was not significant at zero time. However, induction of diabetes led to increase plasma MDA in diabetic group. Meanwhile, after 8 weeks, plasma MDA increased significantly $12.3 \pm 3.0 \mathrm{nmol} / \mathrm{ml}$ in diabetic group compared to normal group. On the other hand, significant decrease was observed in curative group due to ginseng treatment.

The present data showed that after 4 and 8 weeks, plasma MDA levels decreased in ginseng group, but that reduction was not significant compared to normal. Meanwhile, MDA after 8 weeks significantly decreased to $56.58 \%$ in prophylactic group treated with ginseng compared to diabetic group. On the other hand, results of curative study showed that after 4 weeks of treatment with ginseng plasma MDA levels decreased in curative group $35 \%$ compared to diabetic group.

In the present study, it was observed that plasma MDA levels increased significantly after the induction of diabetes in diabetic group compared to normal group. These data are consistent with Slatter et al. (2000) who reported that MDA concentration is increased considerably in diabetes mellitus. The lowering effect of ginseng on MDA level is not clearing known, but the study of Hammouda et al. (1994) mentioned that whether this is an effect of some residual ginseng components or due to alteration of plasma antioxidant mechanism by ginseng cannot be decided.

\section{Glutathione (GSH):}

The prophylactic effect of ginseng on blood GSH in diabetic rats was presented in Table (8) Data revealed that blood GSH at zero time and after 4 weeks was not significantly affected in all groups. However, after 8 weeks the induction of diabetes decreased blood GSH to $51.8 \pm 2.28 \mathrm{mg} / \mathrm{dl}$ in diabetic group compared to $62.7 \pm 3.21$ in normal group. On the other hand, ginseng was significantly led to increase GSH level in normal rats to $74.9 \pm 3.69 \mathrm{mg} / \mathrm{dl}$. 
Moreover, results of curative study obtained in Table (8) revealed that, blood GSH levels after 4 weeks were not changed significantly in diabetic ginseng group after the induction, compared to diabetic control group. However, at the end of experimental period-after 8 weeks, blood GSH was significantly increased to $67.6 \pm 4.43 \mathrm{mg} / \mathrm{dl}$ in curative group compared to $51.8 \pm 2.28$ in diabetic control group.

Table 8. Prophylactic and Curative Effect of Ginseng on Plasma Antioxidants Biomarkers in Normal and Diabetic Female Albino Rats.

\begin{tabular}{|c|c|c|c|c|c|c|}
\hline \multirow[t]{2}{*}{ Parameter } & \multirow{2}{*}{$\begin{array}{l}\text { Weeks } \\
\text { Zero }\end{array}$} & \multirow{2}{*}{$\begin{array}{l}\text { Control } \\
7.42 \\
\pm 1.50\end{array}$} & \multirow{2}{*}{$\begin{array}{l}\text { Ginseng } \\
7.42 \\
\pm 1.10\end{array}$} & \multirow{2}{*}{$\begin{array}{l}\text { Diabetic } \\
7.01 \\
\pm 0.12\end{array}$} & \multicolumn{2}{|c|}{ Prophylactic Curative } \\
\hline & & & & & $\begin{array}{l}7.23 \\
+0.50\end{array}$ & $\begin{array}{l}7.01 \\
+132\end{array}$ \\
\hline \multirow[t]{2}{*}{$\begin{array}{l}\text { MDA } \\
\mathrm{nmol} / \mathrm{ml}\end{array}$} & 4 & $\begin{array}{l}7.53 \\
\pm 1.82\end{array}$ & $\begin{array}{l}5.63 \\
\pm 0.71\end{array}$ & $\begin{array}{l}11.6 \\
\pm 1.92\end{array}$ & $\begin{array}{l}5.24^{\star *} \\
\pm 1.83\end{array}$ & $\begin{array}{l}10.2 \\
\pm 1.53\end{array}$ \\
\hline & 8 & $\begin{array}{l}7.70 \\
\pm 1.10\end{array}$ & $\begin{array}{l}5.23 \\
\pm 1.25\end{array}$ & $\begin{array}{l}12.0 \\
\pm 1.52^{*}\end{array}$ & $\begin{array}{l}5.21 \\
\pm 1.30 \text { ** }\end{array}$ & $\begin{array}{l}7.82 \\
\pm 0.91^{*}\end{array}$ \\
\hline \multirow[t]{2}{*}{$\begin{array}{l}\text { Mean } \\
\pm \text { SE } \\
\end{array}$} & & $\begin{array}{l}7.55 \\
\pm 0.1 \\
\end{array}$ & $\begin{array}{l}6.09 \\
\pm 0.88 \\
\end{array}$ & $\begin{array}{l}10.2 \\
\pm 2.12 \\
\end{array}$ & $\begin{array}{l}5.89 \\
\pm 0.89 \\
\end{array}$ & $\begin{array}{l}8.34 \\
\pm 1.23 \\
\end{array}$ \\
\hline & Zero & $\begin{array}{l}59.2 \\
\pm 2.12\end{array}$ & $\begin{array}{l}58.7 \\
\pm 3.24\end{array}$ & $\begin{array}{l}61.4 \\
\pm 1.75\end{array}$ & $\begin{array}{l}57.4 \\
\pm 3.60\end{array}$ & $\begin{array}{l}60.3 \\
\pm 2.11\end{array}$ \\
\hline \multirow{2}{*}{$\begin{array}{l}\text { Reduced } \\
\text { Glutathione } \\
\text { GSH mg/dl }\end{array}$} & 4 & $\begin{array}{l}66.9 \\
\pm 4.27\end{array}$ & $\begin{array}{l}70.4 \\
\pm 4.31\end{array}$ & $\begin{array}{l}65.2 \\
\pm 5.49\end{array}$ & $\begin{array}{l}60.7 \\
\pm 2.21\end{array}$ & $\begin{array}{l}68.6 \\
\pm 3.09\end{array}$ \\
\hline & 8 & $\begin{array}{l}62.7 \\
\pm 3.21 \\
\end{array}$ & $\begin{array}{l}74.9 \\
\pm 3.69^{*} \\
\end{array}$ & $\begin{array}{l}51.8 \\
\pm 2.28 * \\
\end{array}$ & $\begin{array}{l}60.5 \\
\pm 1.10^{*} \\
\end{array}$ & $\begin{array}{l}67.6 \\
\pm 4.43^{*} \\
\end{array}$ \\
\hline \multicolumn{2}{|l|}{$\begin{array}{l}\text { Mean } \\
\pm \mathrm{SE} \\
\end{array}$} & $\begin{array}{l}62.9 \\
\pm 3.85 \\
\end{array}$ & $\begin{array}{l}68.0 \\
\pm 5.85 \\
\end{array}$ & $\begin{array}{l}59.4 \\
\pm 1.90 \\
\end{array}$ & $\begin{array}{l}59.5 \\
\pm 1.65 \\
\end{array}$ & $\begin{array}{l}65.5 \\
\pm 4.15 \\
\end{array}$ \\
\hline \multirow{3}{*}{$\begin{array}{l}\text { L-Ascorbic } \\
\text { acid (mg/dl) }\end{array}$} & Zero & $\begin{array}{l}1.27 \\
\pm 0.07\end{array}$ & $\begin{array}{l}1.19 \\
\pm 0.08\end{array}$ & $\begin{array}{l}1.16 \\
\pm 0.01\end{array}$ & $\begin{array}{l}1.20 \\
\pm 0.06\end{array}$ & $\begin{array}{l}1.21 \\
\pm 0.08\end{array}$ \\
\hline & 4 & $\begin{array}{l}1.22 \\
\pm 0.06\end{array}$ & $\begin{array}{l}1.23 \\
\pm 0.04\end{array}$ & $\begin{array}{l}0.77 \\
\pm 0.13^{\star *}\end{array}$ & $\begin{array}{l}1.19 \\
\pm 0.07\end{array}$ & $\begin{array}{l}0.68 \\
\pm 0.05^{\star *}\end{array}$ \\
\hline & 8 & $\begin{array}{l}1.07 \\
\pm 0.09 \\
\end{array}$ & $\begin{array}{l}1.36 \\
\pm 0.05^{*} \\
\end{array}$ & $\begin{array}{l}0.58 \\
\pm 0.04^{\star *}\end{array}$ & $\begin{array}{l}1.07 \\
\pm 0.09^{* *} \\
\end{array}$ & $\begin{array}{l}1.20 \\
\pm 0.03^{\star *} \\
\end{array}$ \\
\hline \multirow[t]{2}{*}{$\begin{array}{r}\text { Mean } \\
\pm S E \\
\end{array}$} & & $\begin{array}{l}1.18 \\
\pm 0.07\end{array}$ & $\begin{array}{l}1.26 \\
\pm 0.06\end{array}$ & $\begin{array}{l}0.68 \\
\pm 0.21 \\
\end{array}$ & $\begin{array}{l}1.15 \\
\pm 0.05 \\
\end{array}$ & $\begin{array}{l}0.94 \\
\pm 0.23 \\
\end{array}$ \\
\hline & Zero & $\begin{array}{l}22.8 \\
\pm 0.22\end{array}$ & $\begin{array}{l}21.5 \\
\pm 0.65\end{array}$ & $\begin{array}{l}20.6 \\
\pm 1.25\end{array}$ & $\begin{array}{l}21.2 \\
\pm 0.65\end{array}$ & $\begin{array}{l}23.7 \\
\pm 0.89\end{array}$ \\
\hline $\begin{array}{l}\text { Catalase } \\
\text { umol } \mathrm{H}_{2} \mathrm{O}_{2} / \\
\mathrm{min} / \mathrm{mg} \text { protein } 8\end{array}$ & & $\begin{array}{l}22.3 \\
\pm 0.58 \\
21.4 \\
\pm 1.63 \\
\end{array}$ & $\begin{array}{l}23.1 \\
\pm 1.08 \\
19.5 \\
\pm 0.28 \\
\end{array}$ & $\begin{array}{l}23.6 \\
\pm 0.63 \\
23.6 \\
\pm 1.04 \\
\end{array}$ & $\begin{array}{l}22.0 \\
\pm 1.19 \\
20.4 \\
\pm 0.69 \\
\end{array}$ & $\begin{array}{l}23.9 \\
\pm 0.62 \\
20.7 \\
\pm 2.35 \\
\end{array}$ \\
\hline $\begin{array}{l}\text { Mean } \\
\pm \text { SE }\end{array}$ & & $\begin{array}{l}22.2 \\
\pm 0.51\end{array}$ & $\begin{array}{l}21.3 \\
\pm 1.24\end{array}$ & $\begin{array}{l}23.6 \\
\pm 1.33\end{array}$ & $\begin{array}{l}21.2 \\
\pm 0.53\end{array}$ & $\begin{array}{l}22.7 \\
\pm 1.37\end{array}$ \\
\hline
\end{tabular}

Each value represents the mean of 8 rats \pm S.E; Mean \pm SE after induction of diabetes. ${ }^{*} \&{ }^{\star \star}$ mean Significant \& Highly significant difference at $P<0.05 \& P<0.01$ respectively.

In the present study, the induction of diabetes by STZ caused significant decrease in the blood GSH levels. Meanwhile, treatment with ginseng in prophylactic and curative study restores this reduction. These findings are in agreement with several workers, who reported decreasing level of GSH in experimental diabetic rats (Selvam and Anuradha, 1990 \& Stanly and Menon, 1998). The decreasing levels of GSH in diabetes may be due to increase utilization of GSH in trapping the oxy radicals (Venkateswaran and Pari, 2003). 


\section{Ali, S.H. et al.}

\section{L-Ascorbic Acid (L-AsA):}

Table (8) showed the prophylactic effect of ginseng on blood L-AsA levels. Data obtained revealed that blood L-AsA at zero time and after 4 weeks, were not significantly affected in all groups. However, the induction of diabetes with STZ, significantly decreased blood L-AsA to $0.77 \pm 0.13 \mathrm{mg} / \mathrm{dl}$ in diabetic control group compared to $1.22 \pm 0.06 \mathrm{mg} / \mathrm{dl}$ in normal control group. Moreover, treatment with ginseng significantly increased blood L-AsA to 1.07 $\pm 0.09 \mathrm{mg} / \mathrm{dl}$ in ginseng diabetic group compared to diabetic control group. While, in ginseng group, blood L-AsA levels increased to $1.36 \pm 0.05 \mathrm{mg} / \mathrm{dl}$. However, these values are significant compared to normal control group (1.07 $\pm 0.09 \mathrm{mg} / \mathrm{dl})$.

On the other hand, Table (8) showed the curative effect of ginseng on blood L-AsA level. Results obtained reveal that, at zero time, there was not significant variation between all groups. However, after 8 weeks of treatments, blood L-AsA significantly increased to $1.20 \pm 0.03 \mathrm{mg} / \mathrm{dl}$ in curative group compared to diabetic group $(0.58 \pm 0.04 \mathrm{mg} / \mathrm{dl})$. The present results agreed with Selvam and Anuradha, (1990); Stanly and Menon, (1998); Venkateswaran and Pari (2003) who found lowering in levels of vitamin C in experimental diabetic rats.

Building upon previous research showing 3 grams of ginseng led to decrease and help stabilize blood sugar levels (Vuksan et al., 2000a \& $2000 \mathrm{~b})$, researchers isolated the fat cells of rats to see if Ginseng Extract (GE) could inhibit lipolysis (fat breakdown). Surprisingly, they found that GE inhibited lipolysis by 49 percent from baseline, thereby improving blood sugar levels and increasing insulin sensitivity. When trying to determine how ginseng was able to exert these effects, the researchers speculated that GE increased the activation of an enzyme called PDE4, an enzyme that has gained attention for its ability to possibly help the treatment of a wide range of inflammatory diseases from asthma to lung disease (Houslay, 2005).

\section{Catalase (CAT):}

Table (8) revealed the prophylactic effect of ginseng on CAT activity in normal and diabetic rats. Data revealed that CAT activity at zero time and after 4 weeks was not significantly affected in all groups. However, after 8 weeks, the induction of diabetes by STZ slightly increased CAT activity to (23.6 $\pm 0.63 \mathrm{umol} \mathrm{H}_{2} \mathrm{O}_{2} / \mathrm{min} / \mathrm{mg}$ protein) in diabetic control group compared to normal control group ( $21.4 \pm 1.63 \mathrm{umol} \mathrm{H}_{2} \mathrm{O}_{2} / \mathrm{min} / \mathrm{mg}$ protein).

Curative effect of ginseng on CAT activity in diabetic rats was tabulated in Table (8). Data obtained revealed insignificant variation between all groups at zero time before the induction of diabetes. However, after the induction of diabetes CAT activity was slightly increased in diabetic groups compared to normal control group. On the other hand, after 8 weeks of treatment with ginseng CAT activity showed insignificant decrease to $20.7 \pm$ $2.35 \mathrm{umol} \mathrm{H}_{2} \mathrm{O}_{2} / \mathrm{min} / \mathrm{mg}$ protein compared to diabetic group.

The present results showed that, the induction of diabetes with STZ showed insignificantly increase in CAT activity after 4 weeks in diabetic group. These findings are in agreement with those obtained by Torres et al. (1999) who found that, the levels of erythrocyte CAT activity in diabetic rats were 
greater than in the normal rats. Also, results agreed with Cekic et al. (1999) who measured the activity of CAT in the lenses of diabetic and normal rats, and found that, CAT activity increased in diabetic rats compared with normal rats. However, Kedziora-Kornatowska et al.(2000) reported that, the induction of diabetes resulted in a decrease of CAT activity after 6 and 12 weeks.

On the other hand, results of prophylactic and curative studies showed that, treatment with ginseng root insignificantly decrease CAT activity in diabetic rats and normal treated with ginseng after 8 weeks of induction of diabetes compared to diabetic group. In contrary, the results obtained by Deng and Zhang (1991) showed that catalase activity was reported to be increased under the effect of ginsenoside Rb1 and RG1.

\section{CONCLUSION}

Oxidative stress was involved in the early diabetic cases that not only led to reduce the activities of antioxidant enzymes, but also they reduce antioxidants capacity and plasma membrane dysfunction due to lipid peroxidation. However, ginseng supplementation increased activities of antioxidant enzymes and improved plasma membrane function. The study indicated that ginseng was beneficial to the treatment of diabetic rats due partly at least to its antioxidant property.

Physicochemical, biochemical, and cellular assays confirmed that ginseng inhibits the formation of reactive oxygen radicals and lipid peroxidation, scavenged oxygen free radicals, and prevented the depletion of endogenous anti-oxidants which that ginseng may provide greater benefit for hyperglycemia and diabetes mellitus for its antioxidant actions that synergize with it. Finally the current work indicated that more attention should be accomplished to natural plants to protect and cure human bodies from oxidative damage and maintain healthy body, also, makes strong defense system for the cells from environmental abiotic and biotic stress.

\section{REFERENCES}

Akula, A.; Kota, M.K.; Gopisetty, S.G.; Chitrapu, R.V.; Kalagara, M.; Kalagara, S.; Veeravalli, K.K. and Gomedhikam, J.P. (2003). Biochemical, histological and echocardiographic changes during experimental cardiomyopath in STZ-induced diabetic rats. Pharmacol. Res., 48(5): 429-435.

Ali,S.H. (1991). Biochemical Studies on the Effect of Some Hormones on the Metabolism of Experimental Rats. Ph.D.Thesis, Biochem. Dept. Fac. Agric. Ain Shams Univ.

Aphala, A.A.; Chhibba, A.D.; Kumbhakarna, N.R. and Mateenuddin, M. (1998). Subacute toxicity study of the combination of ginseng (Panax Ginseng) and ashwagandha (Withanina Somnifera) in rats. Indian J. Physiol. Phamacol., 42(2): 299-302.

Attele AS, Wu JA, Yuan C-S. (1999). Ginseng pharmacology: multiple constituents and multiple actions. Biochem Pharmacol; 58: 1685-1693 


\section{Ali, S.H. et al.}

Attele, A. S.; Zhou, Y. P.; Xie, J. T.; Wu, J.A.; Zhang, L.; Dey, L.; Pugh, W.; Rue, P.A; Polonsky, K.S. and Yuan, C.S. (2002). Antidiabetic effects of Panax ginseng berry extract and the identification of an effective components. Diabetes, 51: 1851-1858.

Baynes, J.W. (1992). Perspectives in diabetes. Role of oxidative stress in development of complications in diabetes. Diabetes, 40 (4): 405-412.

Beutler, E.; Duron, O. and Kelly, B.M. (1963). Improved method for the determination of blood glutathione. J. Lab. Clin. Med., 16(5): 882-890.

Bradford, M.M. (1976). A rapid and sensitive method for the quantitation of microgram quantities of protein utilizing the principle of protein-dye binding. Anal. Biochem. 72, 248-254.

Cai L, Kang YJ. (2003). Cell death and diabetic cardiomyopathy. Cardiovasc Toxicol. 3(3):219-228.

Cekic,O.; Bardak,Y.; Totan,Y.; Akyol,O. and Zilelioglu,G. (1999). Superoxide dismutase, catalase, glutathione peroxidase and xanthine oxidase in diabetic rat lenses. Ophthalmic. Res. 31(5): 346-50.

Chase, C.I. (1967). Statistical analysis of data using t-test according to the degree of freedom. Elementary Statistical Procedures McGrow Hill, Book Comp. p. 140.

Cho EJ, Yokozawa T, Kim HY, Shibahara N, Park JC. (2004). Rosa rugosa attenuates diabetic oxidative stress in rats with streptozotocin-induced diabetes. Am J Clin Med.; 32(4):487-96.

Damasceno,D.C.; G.T.Volpato; I.de-Mattos-Paranhos-Calderon and M.V.Cunha (2002). Oxidative stress and diabetes in pregnant rats. Anim.Reprod.Sci. 72(3-4):235-244.

Deng, H.L. and Zhang, J.T. (1991). Anti-lipid peroxidative effect of ginsenoside Rb1 and Rg1.Chin. Med. J., 104: 395-398.

Dey,L.; Xie,J.T.; Wang, A.; Wu, J.; Maleckar, S.A. and Yuan, C.S.(2003). Anti-hyperglycemic effect of ginseng: comparison between root and berry. Phytomedicine, 10 (6-7): 600-605.

Dincer,Y.; A.Telci; R.Kayali; I.A.Yilmaz; U.Cakatay and T.Akcay (2002). Effect of alpha-lipoic acid on lipid peroxidation and antioxidant enzyme activities in diabetic rats. Clin. Exp. Pharmacol. Physiol. 29 (4):281-284.

Flegg, H.M. (1973). An investigation of the determination of serum cholesterol by an enzymatic method. Ann. Clin. Biochem., 10: 79-84.

Fossati, P. and Prencipe, L. (1982). Serum triglycerides determined colorimetrically with an enzyme that produces hydrogen peroxide. Clin. Chem., 28 (10): 2077-80.

Friedewaled W.T.; Leveey R.I and Fredrickson D.S. (1972). Estimation of plasma low density lipoprotein cholesterol concentration without use of the preparative ultracentrifuge. Clin. Chem. 18:499-509.

Fruchart, J.C. (1982). Rev Fr. Des Laboratories, 105: 7-17, as quoted from pamphlet of bio Merieux.

Gallaher, D.D.; Olson, J.M. and Larntz, K. (1992). Dietary guar gum halts further renal enlargement in rats with established diabetes. J. Nutr., 122: 2391- 2397.

Ganong, W.F. (1983). Quoted from review of Medical physiology. $11^{\text {th }}$ Ed. Lang Med. Public. Chapter 19: 268-288. 
Hammouda, M.A.; Abou-Shouk, T. and El-Esawy, A.A. (1994). Effect of ginseng on lipid peroxidation. Egypt. J. Biochem., 12 (1\&2): 101-108.

Helms S. (2004). Cancer prevention and therapeutics: Panax ginseng. Altern Med Rev.; 9(3): 259-74.

Houslay MD, Schafer P, Zhang KY. (2005). Keynote review: phosphodiesterase-4 as a therapeutic target. Drug Discov.Today.10(22):1503-19.

Huang, He; Jiang Shan, Xiao-hong Pan, Hui-ping Wang, and Ling-bo Qian (2006). Carvedilol protected diabetic rat hearts via reducing oxidative stress. J Zhejiang Univ Sci B. ; 7(9): 725-731.

Jagota S.K. and Dani, H. M. (1982). A new colormitric technique for the estimation of vitamin C using folin phenol reagent. Anal. Biochem., 127: 178-182.

Jang JH, Surh YJ. (2003). Potentiation of cellular antioxidant capacity by Bcl2: implications for its antiapoptotic function. Biochem Pharmacol.; 66(8):1371-1379.

Jung $\mathrm{CH}$, Seog HM, Choi IW, Choi HD, Cho HY. (2005). Effects of wild ginseng (Panax ginseng C.A. Meyer) leaves on lipid peroxidation levels and antioxidant enzyme activities in streptozotocin diabetic rats. J. Ethnopharmacol. 26;98(3):245-50.

Kaneko H., Nakanishi K. (2004). Proof of the mysterious efficacy of ginseng: basic and clinical trials: clinical effects of medical ginseng, korean red ginseng: specifically, its anti-stress action for prevention of disease. J. Pharmacol Sci. ;95(2):158-62.

Kedziora-Komatowska, K. Z.; Luciak, M. and Paszkowski, J. (2000). Lipid peroxidation and activities of antioxidant enzymes in the diabetic kidney: effect of treatment with angiotensin convertase inhibitors. IUBMB-Life, 49 (4).

Kim, S.H. and Park, K.S. (2003). Effect of panax ginseng extract on lipid metabolism in humans. Pharmacol. Res., 48 (5): 511-3.

Kimura, M.; Suzuki, S and Imamura, M. (1981). Mechanisms of insulin release stimulated by the hypoglycaemic components (DPG 3-2) in ginseng radix. Proc. Symp. Wakan-Yaku- 41: 129-132.

Knight, J.A.; Anderson,S. and Rawle, J.M.(1972). Chemical bases of the sulfo phospho-vanillin reaction for estimating serum total lipids. Clin. Chem., $18(3)$.

Lian,XY;Z.Zhang;JL.Stringer(2005)."Protective effects of ginseng components in a rodent model of neurodegeneration." Ann Neurol 57(5): 642-8.

Mahady,GB; C.Gyllenhall; H.H.Fong and N.R.Farnsworth (2000). Ginsengs: a review of safety and efficacy. Nutr Clin Care. 3:90-101.

Mansour, H.A.; Newairy, A.S.; Yousef, M.I. and Sheweita, S.A. (2002). Biochemical study on the effects of some Egyptian herbs in alloxaninduced diabetic rats. Toxicology., 170 (3): 221-8.

McDermott, B.M.; J.J. Strain and P.R. Flatt (1955). Effects of dieetary carbohydrate intake on antioxidant enzyme activity and copper status in the copper-defficient streptozotocin (STZ) diabetic rats. Nutritional Biochemistry. 6,638-643. 
Ali, S.H. et al.

Morgan, A. and Cupp, M.J. (2000). Forensic Science: Toxicoloy and clinical pharmacology of herbal products. Edited by: Cupp, M.J. Humana Press Inc., lotowa, New Jersey, 12: 141-153.

Murase, K.; Yamamoto, T. and Hyaski, K. (1994). Nerve growth factor-like immunoreactive substance in panax ginseng extract. Biosci. Biotech. Biochem., 58 (9): 257-259.

Nandini,C.D.; Sambaiah,K. and Salimath,P.V. (2003). Dietary fibers ameliorate decreased synthesis of heparan sulphate in sterptozotocin induced diabetic rats. Journal of Nutritional Biochemistry, (14): 203210.

Nariman, K.B. (1997). Effect of panax ginseng extract on the nepherotoxicity of streptozotocin-induced experimental diabetes. Egyp. J. Biochem., 15 $(1-2): 29-52$.

Nishijo H, Uwano T, Zhong YM, Ono T. (2004). Proof of the mysterious efficacy of ginseng: basic and clinical trials: effects of red ginseng on learning and memory deficits in an animal model of amnesia. $J$ Pharmacol Sci;:95(2):145-52.

Obrosova, I.G.; Minchenko, A.G.; Vasupuram, R.; White, L.; Abatan, O.I.;Kumagai, A.K.; Frank, R.N. and Stevens, M.J. (2003). Aldose reductase inhibitor fidarestat prevents retinal oxidative stress and vascular endothelial growth factor overexpression in streptozotocindiabetic rats. Diabetes, 52: 864-871.

Osfor, M.M.H.; Badawy, I.; Nagwa, A.M. Abdel Gafar and Kutat, M.A. (2002). Immunological studies on the effect of panax ginseng on the nutritional value of food in albino rats. Egypt. J. Food Sci., 30 (1): 125-143.

Paul, N. (1997). Hyperlipidaemia diagnosis and management. Butter worth Helnemann university press. Text BooK of DM $2^{\text {nd }}$ Ed.: 227-229.

Pieper,G.M.; M.Jardon; L.A.Dondlinger; M.B.Adams and A.M.Roza (1995). Peroxidative stress in diabetic blood vessels. Reversal by pancreatic iselt transplantation. Diabetes, 44(8):844-889.

Predy G.N., Vinti Goel, Ray Lovlin, Allan Donner, Larry Stitt and Tapan K. Basu (2005). Efficacy of an extract of North American ginseng containing poly-furanosyl-pyranosyl-saccharides for preventing upper respiratory tract infections: a randomized controlled trial. CMAJ.;173(9):1043-8.

Ramanathan, M.; A.K.Jaiswal and S.K.Bhattacharya (1999). Superoxide dismutase, catalase and glutathione peroxidase activities in the brain of streptozotocin induced diabetic rats. Indian J.Exp.Biol. 37 (2):182-183.

Renu,A.K. (2003).Effect of reinstitution of good glycemic control on retinal oxid-ative stress and nitrative stress in diabetic rats. Diabetes, (52): 818-823.

Said, M.M; Abd El-Latif, H.H; Nour, A.M.; Zohni, M.S. and Abd El- Rahman, A.A. (2000). Biochemical effects of some natural products on normal rats and their protective effects against hyperglycemia. J. Drug Res. Egypt, 23: 239-250.

Schermer, S. (1967). In "The Blood Morphology of Laboratory Animals" $3^{\text {th }}$ Ed. p.42.Pbl. F. A. Davis Co. Philadelphia USA. 
Selvam, R. and Anuradha, C.V. (1990). Effect of oral methionine on blood lipid peroxidation and antioxidants in alloxan induced diabetic rats. J. Nutr. Biochem. 1: 653-658.

Sinha, A. S. (1972). Colorimetric assay of catalase. Anal. Bioch. 47, 389-394.

Slatter,D.A; Bolton,C.H. and Bailey,A.J. (2000). The importance of lipidderived malondialdehyde in diabetes mellitus. Diabetologia, 43 (5): 550557.

Smith, D.C.; Habito, R.; Barnett, M. and Collier, G.R. (1997). Dietary guar gum improves insulin sensitivity in streptozotocin-induced diabetic rats. J. Nutr., 127 (2): 359-364.

Stahl,W. and Sies,H. (1997). Antioxidants defense: Vitamins E and C and carotenoids. Diabetes, 46 (2): S14-S18.

Stanly, M.P.P. and Menon, V.P. (1998). Effect of syzigium cumini in plasma antioxidants on alloxan induced diabetes in rats. J. Clin. Biochem. Nutr., 25: 81-86.

Strove, E.A. and Makarova, V.G. (1989). Laboratory Manual in Biochemistry. $1^{\text {st }}$ Ed. Mir. Publishers Moscow. pp. 251-253.

Takaku, T.; Kameda, K.; Matsuura, Y.; Sekiya, A. and Okuda, H. (1988). Studies on insulin-like substance in Korean red ginseng. Planta Medica, 56: 27-30.

Torres, M.D.; Canal, J.R. and Perez, C. (1999). Oxidative stress in normal and diabetic rats. Physiol. Res., 48 (3): 203-208.

Trinder, P. (1969). Periodochrom glucose GOD-PAP- method. Ann. Clin. Biochem. 6. 24.

Uchiyama,M. and Mihara,M. (1978).Determination of malonaldehyde precursore in tissues by thiobarbitric acid test. Anal. Biochem., 86: 271278.

Van Kampen, E.J. and Zijlstra, W.G. (1961). Standardization of hemoglobinometry.II. The hemiglobincyanide method. Clin. Chim. Acta. 6,538-544.

Venkateswaran, S. and Pari, L. (2003). Effect of Coccinia indica leaf extract on plasma antioxidants in streptozotocin-induced experimental diabetes in rats. Phytother. Res., 17: 605-608.

Vuksan V.,MP Stavro, JL Sievenpiper, U Beljan-Zdravkovic, LA Leiter, RG Josse and Z Xu (2000). Similar postprandial glycemic reductions with escalation of dose and administration time of American ginseng in type 2 diabetes. Diabetes Care 23: 1221-1226

Vuksan V.; John L. Sievenpiper; Vernon Y. Y. Koo; Thomas Francis; Uljana Beljan-Zdravkovic; Zheng Xu; Edward Vidgen, (2000). American Ginseng (Panax quinquefolius L) Reduces Postprandial Glycemia in Nondiabetic Subjects and Subjects With Type 2 Diabetes Mellitus. Arch Intern Med.;160:1009-1013.

Wang H., Lisa A. Reaves and Neilé K. Edens (2006). Ginseng Extract Inhibits Lipolysis in Rat Adipocytes In-vitro by Activating Phosphodiesterase 4. J. Nutr. 136: 337-342

Wasif, M.M. (1997). Morus Alba Plant as an antidiabetic agent. Egyptian J. Nutr., XII (1): 113-144. 


\section{Ali, S.H. et al.}

Wolff,S.P. and R.T.Dean (1987). Glucose autoxidation and protein modification: the potential role of autoxidative glycosylation in diabetes. Biochem.J. 245:243-250.

Yamamoto, M.; Uemura, T.; Nakama, S.; Uemiya, M. and Kumagai, A (1983). Serum HDL-cholesterol increasing and fatty liver improving actions of panax ginseng in high cholesterol diet fed rats with clinical effect on hyperlipidemia in man. Am. J. Chin. Med., 11: 96-101.

Yu, C.T.; Chen, J.; Teng, X.W.; Tong, V. and Chang, T.K. (2005). Lack of evidence for induction of CYP2B1, CYP3A23, and CYP1A2 gene expression by panax ginseng and panax quinquefolius extracts in adult rats and primary cultures of rat hepatocytes. Drug Metab. Dispos., 33 (1):19-22.

Zhou W.; Chai H; Lin PH; Lumsden AB; Yao Q; and Chen CJ. (2004). Molecular mechanisms and clinical applications of ginseng root for cardiovascular disease. Med. Sci. Monit:;10(8):RA187-92. 


\section{الجنسـج وقائيـا أو علاجيـا يثبط ارتفـاع سـر الـدم والإجهـاد التأكسدى فى الفئران

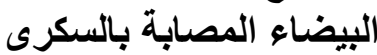 صفوت حسن على*، إيفيلين سـعيد عبداللهـ**، مصطـفى محمد سـعيد** و صباح عفيفى

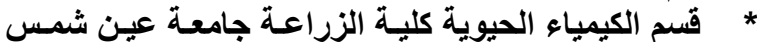

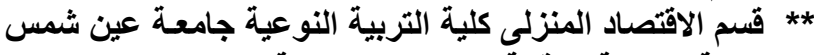

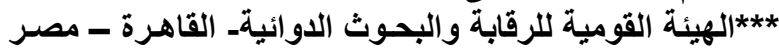

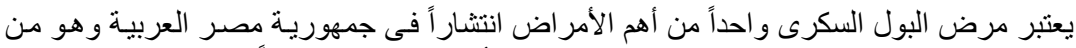

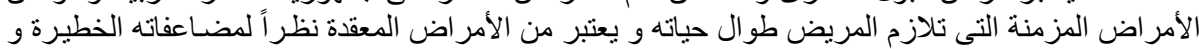

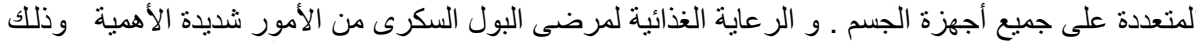

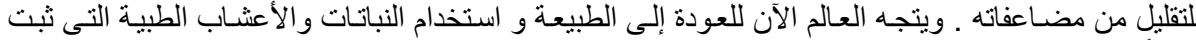

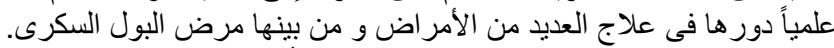

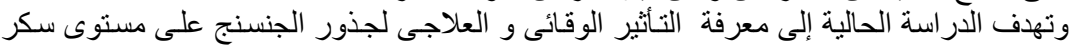

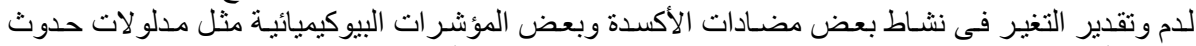

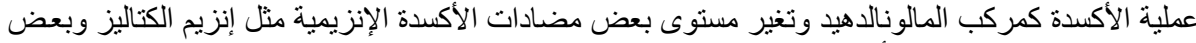

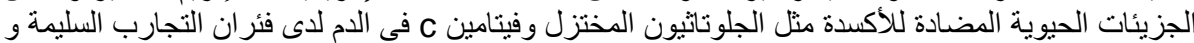

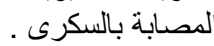

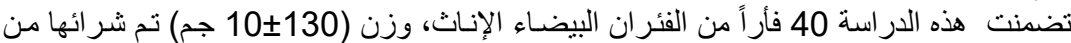

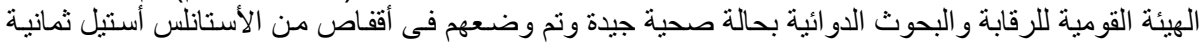

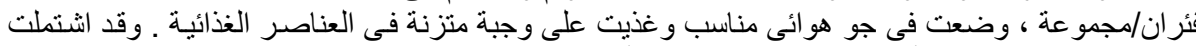

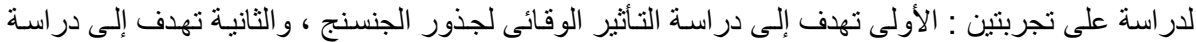

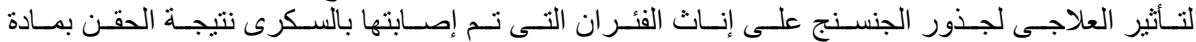

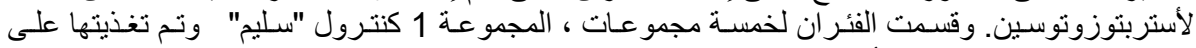

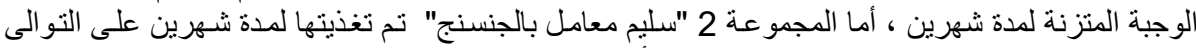

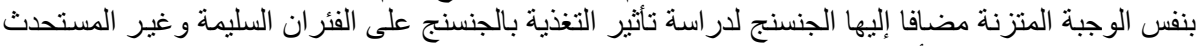

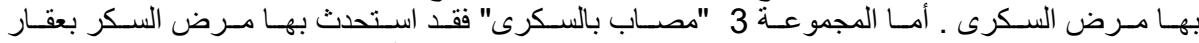

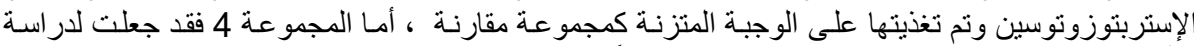

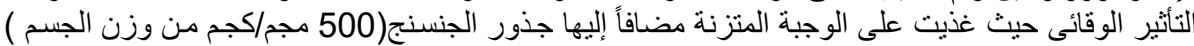

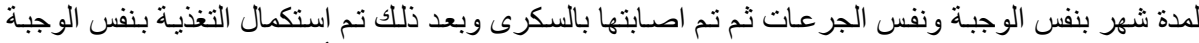

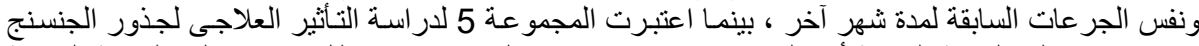

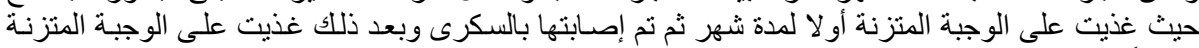

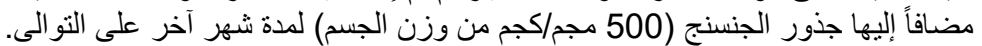

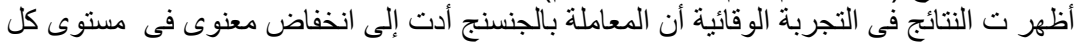

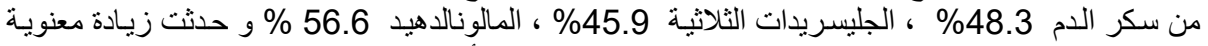

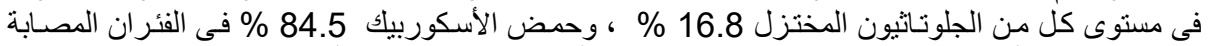

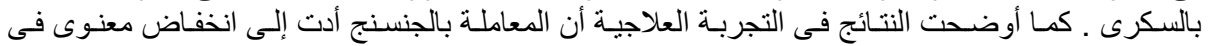

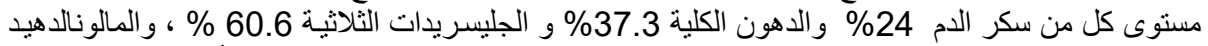

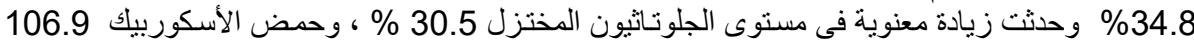

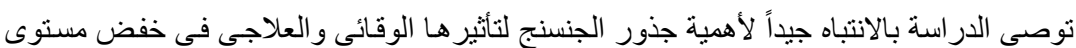

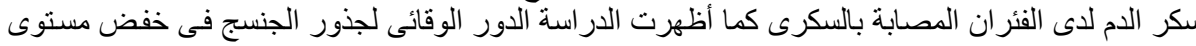

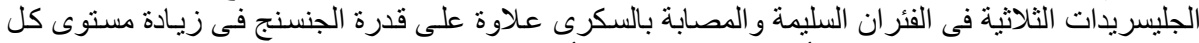

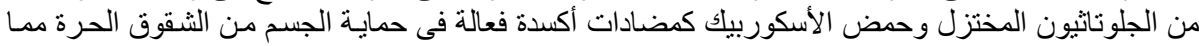
يعمل على الحفاظ على حيوية خلايا الجسم سليمة من مهاجمة الثقوق الحرة الحئ. 